No. 6(57), 2018, pp. 189-214

https://doi.org/10.12797/Politeja.15.2018.57.11

\author{
Andrea SCHMIDT \\ University of Pécs \\ schmidt.andrea@pte.hu
}

\title{
THE UNCERTAIN REVIVAL OF CENTRAL EUROPE
}

\section{(THE CENTRAL EUROPEAN THOUGHT \\ FROM THE HUNGARIAN PERSPECTIVE)}

ABSTRACT The recent crisis the European Union had to face raised the question it there still exists a cleavage that divides the "old Europe" from the Eastern regions. The phenomenon, Central Europe can be examined from the historical, cultural, geographic and political perspective searching for the answer, how many parts the European continent can be divided into. Accepting the tripartite division, this "middle" position had various roles in the historical context. The aim of the paper is to investigate the changes in the perception of this special position based mostly on the works of Hungarian researchers. Analysing their thoughts, it is also our intention to examine the Central European concept and to point how this region was searching for its position during the system change, and what additional meaning was given to this region from the 1980s to nowadays. In order to extend the investigation, this paper also focuses on the problem whether Central Europe serves as a historical reference point losing its importance with the European integration, or if it can serve as an obstacle in the deepening of the European integration.

Key words: transformation, historical region, bordering, periphery 
We have the chance to transfer Central Europe from a phenomenon that has so far been historical and spiritual into a political phenomenon. We have the chance to take a string of European countries that until recently were colonised by the Soviet Union which would be founded on equal rights, and transform them into a definite special body; which would approach Western Europe not as a poor dissident or a belpless, searching amnestied prisoner, but as someone who has something to offer. (Havel) $)^{1}$

If we look back, we can see how the concept of Central Europe has never been perfectly defined. It has been mostly connected to the willingness of discovering certain imaginary and to the importance of overthrowing the regime in order to assert that its identity somehow was lost during the period of Communist rule. It was mainly characterized by the idea that the identity of a nation is based on a shared heritage with the Western World, making the area more similar to the West than to the East. Only after the 1980s, would that definition become part of common usage and accepted as real, representing any imagery, or something abstract. It meant to do tabula rasa of the Soviet past and to highlight instead, that European identity, once lost. ${ }^{2}$

$\mathrm{T}$ he recent crisis, that the European Union has to face necessarily raises the question what Europeanness means and if there still exists a cleavage that divides the "old Europe" from the previously neglected but ambitious Eastern regions. It is also an often recurring question how many parts the European continent can be divided into, or, if there are more groups of states, how Central Europe can be identified, and finally, if there is any cohesion among the states belonging to this particular region. Writing about Central Europe and its position in the continent is quite challenging. The phenomenon itself suggests approaches from the historical, cultural, geographic and political perspective, although even scholars have various views regarding the location and the meaning of Central Europe. The terminology, itself suggestive of a 'middle' position, is often linked to the characterization of the area as lands in between, where East and West meet, a meeting conceived of in a variety of ways (for example, in one formulation the region is a "child of the West who later married the East", while elsewhere it is a mixture of the Eastern and Western). ${ }^{3}$ Central Europe has also been defined as the area of German cultural influence; the area, closest to and under the strongest Western influence, the area of the Habsburg Empire; the area of the Polish-Lithuanian

1 V. Havel, "Allocution prononcée devant la Diéte et le Sénat polonais. Varsovie, le 25 janvier 1990”, in L'angoisse de la Liberté, Paris, Éditions del'aube, pp. 68-78; K. Denni, "Central Europe as a Transition Zone between East and West", Traditiones, vol. 38, no. 2 (2009) pp. 59-71.

2 At <http://www.fomoso.org/en/opinions/commentaries/the-new-tragedy-of-central-europe/>, 24 September 2018.

3 N. Berend, P. Urbańczyk, P. Wiszewski, Central Europe in the High Middle Ages: Bohemia, Hungary and Poland, c. 900-c.1300, Cambridge 2013. 
Commonwealth; the area whose Eastern limits correspond to the Eastern frontiers of the medieval kingdoms, in turn corresponding to the frontier between the Catholic West and the Orthodox East; the area where East and West meet; the easternmost area that has a Western cultural orientation; a cultural zone; the countries that joined the EU in 2004 and 2007 or in 2013, or are on the way to join; a community of destinies in times of crisis alone; and an area shaped by a whole host of historical developments. Central Europe thus is a flexible concept. The meaning of this phenomenon changed several times in the past and was complemented with various elements. The aim of this paper is to give an outline of what is meant by Central Europe, the meaning and the legacy of the region based on works written from the Hungarian point of view. It is also our intention to summarize the Hungarian standpoints and to find out whether these views were in accordance with the ideas proposed in the international context. As it is probably impossible to give a complete analysis, we try to focus on some reference points only. The debate on Central Europe influenced the Hungarian political discourse, the location and the orientation of Hungary acquired significance after the collapse of the Habsburg Monarchy. It was also on the agenda of political programmes in the interwar period, while during the bipolar system both outside Hungary and within the state different visions were developed that provoked further discussions. The late 1980s were the time of a new discourse on Central Europe, while the Euro-Atlantic integration opened a new chapter in the debates. The legacy of Central Europe was questioned several times and as it is explained in this paper in more detail, even the scope of the concept of Central Europe was ambiguous.

\section{THE REDRAWN CENTRAL AND EASTERN EUROPE AND THE UNCERTAIN BORDERS}

While discussing the legacy of Central Europe, it can be stated that its extent is not a constant notion. What is characteristic of the region is that over the past century, East Central Europe has experienced the disappearance, appearance, expansion, shrinking, and shifting of nation states and of the borders defining their territories.

From another perspective Central Europe can also be defined as a geopolitical unity with a common past and interests, located at the borders of the great powers' sphere of interest, or as a group of states forced to coexist in a semi-peripheral position commonly experiencing the structures of global inequality, or states that are facing economic, social and political challenges and solutions. Furthermore, Central Europe can be defined as an area of dreams, rebellion, and a story-sensitive narrative. ${ }^{4}$

The extent of the territory partly depends on the period which serves as its basis. For example, if the designation is based on the later medieval kingdoms of Bohemia, Poland-Lithuania and Hungary, that, in modern terms, translates to the Czech

Közép Európa. Felejtsük el?, 2000 folyóirat, 2014/12, at <http://ketezer.hu/2015/05/kozep-europafelejtsuk-el-5/>, 23 September 2018. 
Republic, Slovakia, Hungary, Poland, Lithuania, Belarus, Ukraine, Croatia and Transylvania (i.e. part of Romania). ${ }^{5}$

Examining the borders of Central Europe, some kind of uncertainty can be recognised, or, as it is worded in political geography, changeability depending on the actual geopolitical aspirations. ${ }^{6}$ Central Europe's history is characterised by two tendencies: the idea of unity, which implies a homogeneous region, and resistance to these efforts and the struggle for the people living in Central Europe. ${ }^{7}$ The historical and geopolitical notion of Central Europe, as Jacque Le Rider remarks in his book La Mitteleuropa, does not correspond to a defined geographical reality and for this reason the term "Central Europe" can be seen as ambiguous.

When analysing the internal borders of Europe, a 1954 article by Karl Sinnhuber, the famous geographer, can serve as a reference point. He examined how twelve well-known British, French and German maps of Central Europe had in common only the bulk of Czechoslovakia and adjacent snippets of some of its neighbours; The only areas they all had in common were Austria, Bohemia, and Moravia. ${ }^{8}$ Sinnhuber also cam to the conclusion, that the versions of Central Europe raised since the early $19^{\text {th }}$ century cover the major part of the core area and practically only the Iberian Peninsula is missing from that. ${ }^{9}$

As Okey remarks, until 1904 there was no influential attempt to define the Central European "symphony" in physical terms. He quotes Joseph Partsch's image of the "triple chord" of Alps, incorporating Denmark, Switzerland, small parts of Italy and France and large parts of the Balkans alongside Germany and the Habsburg Monarchy. The Austrian Hugo Hassinger mentioned "a clearly determined, unambiguous picture of Central Europe as a geographic concept”, while Karl Haushofer called Mitteleuropa „a concept of political will, open to every variety of political interpretation, redefinition and distortion." 10

The notion of Central Europe as a region has been questioned several times. Apart from the historical context, the cataclysms that were followed by the remapping of the regions, a considerable number of geographers were unconvinced even about the legacy of Central Europe. One of them was the Austrian scholar, Erwin Hanslik who "stated emphatically during the First World War that Central Europe was only a phantom of the imagination and other than along the line from Trieste via Vienna, Prague and

5 N. Berend, P. Urbańczyk, P. Wiszewski, Central Europe...

$6 \quad$ P. Miletics, V. Pál, “A közép-európai tér fejlődésének kérdései”, Földrajzi Értesito”, no. 2 (1998), pp. 217 -233; R. Okey, "Central Europe / Eastern Europe, Behind the Definitions", Past and Present, vol. 137, no. 1 (1992); The Cultural and Political Construction of Europe pp. 102-133.

K. Denni “Central Europe as a Transition Zone...”, pp. 59-71.

$8 \quad$ "Tell me your Central Europe and I will tell you who you are." (Gash) Timothy Garton Ash also used Sinnhuber's classification as the reference point for further investigation about the similarities and differences of the two parts of Europe including the legacy of Central Europe as a separate entity within the continent.

9 T. Hardi, "Various Mental Images about the Geographical Extension of Central, Southeast and Eastern Europe”, Bulletin of Geography. Socio-economic Series, no. 31 (2016), pp. 129-143.

10 R. Okey, “Central Europe / Eastern Europe...", p. 103. 
Breslau to Königsberg, the East began without any transition. Mackinder, the British geographer was also sceptic about the existence of Central Europe as a region. In his work Democratic Ideals, and in his concept there was no space for Central Europe however he referred the river Elbe as a cleavage between East and West, furthermore, his concept focused on the importance of Eastern Europe. „He who controls Eastern Europe controls the world." ${ }^{11}$ The similar sceptical argument was made in the inter-war period by the French historian, Joseph Aulneau when he stated that Central Europe was no entity and existed only in the minds of the conquerors sand writers. ${ }^{12}$

This standpoint is accepted in Hungary, too. The classification is based on the concept that there existed four typical approaches regarding the division of Europe. ${ }^{13}$ Two of these insist on the dual structure of the region; an Eastern and a Western part, which are fragmented and divided into several sub-regions, which can be different in certain respects, but as a whole several common features can be observed. These are the similarities ar based on their social structure, the institutional framework, and also appears in common values. ${ }^{14}$

The other distinction, on the other hand, is based on the tripartite structure of Europe with an additional region between East and West having special geopolitical location, development path and differing from the East and West by its special strategic goals. Illés however, emphasizes that this in-between position cannot be defined as a separate "third road" or as a final target to approach, as it is rather the part of a historical endeavour, how to face the challenges following from this special location. Regarding the borders Illés also shares the view that the river Elbe can serve as the border between East and West that was almost identical with the extension of the Oder, i.e. the Eastern border of the European Union before 2004 that corresponds with Wallerstein's division. According to this classification the European continent of the $18^{\text {th }}$ century can be characterized as a tripartite construct: ${ }^{15}$

1. A more developed epicentre - a central core or plateau, the developed countries with elements of capitalism, the free market, global division of labour, including the existence of independent political units (in this case, states) at the same time. There is no political centre, as opposed to global empires.

2. A periphery - a synonym for the dependent developing countries. The main reason for the position of the developed countries is economic power.

$11 \quad$ Ibid., p. 104.

12 At <https://www.gla.ac.uk/0t4/crcees/files/summerschool/readings/school10/reading_list/Sinnhuber.pdf $>, 23$ September 2018.

13 I. Illés, Közép-és Dél-Kelet-Európa az azredfordulón, Budapest 2002, pp. 16-18.

14 This standpoint has changed throughout the past centuries as the division of Europe, or the question itself if Europe could be divided into two or three parts was determined if it was discussed during the age of socialism when the mainstream approach referred to the division of Europe into two major parts when the socialist bloc and the Soviet Union were located in the same group and the extension of Eastern Europe ended at the Ural mountain.

15 I. Wallerstein, A modern világgazdasági rendszer kialakulása. A tökés mezögazdaság és az európai világgazdaság eredete a XVI. században, Budapest 1983. 
3. A semi-periphery - states that are located between the core and the periphery. They are influenced by the core area, but there are characteristic features that make them similar to the periphery, too.

It can be said that this tripartite division has survived for centuries. This history-based heritage, however, has remained in Europe by forming a dichotomous structure. The differences can be expressed in terms of the following oppositions: nation state or global governance, representation of local or global interests, federalism or strong nation state. The questions of the role of religion and the national language are also important. A few other terms have been coined by medievalists for the countries, such as 'younger Europe,' 'newcomers' to Europe or 'third Europe.. ${ }^{16}$

The other classification based on the values in politics and culture appears in Huntington's, Bidlo's and Halecki's argumentation. This division also focuses on the dual structure of the European continent, however it puts more emphasis on cultural values. The region is marked by "relative economic and institutional backwardness (compared to the West $)^{17}$; a relative abundance of labour; relative instability of state in the population. In themselves these historical factors can be hardly denied. In the Habsburg Empire, both the openness of borders and ethnic diversity were seen as resources rather than as defects.

Apart from political and economic values the tripartite structure is influenced by historical and social preconditions. This central region was identified in the historical past with German efforts at economic and political dominance, with Neumann's Mitteleuropa concept, the Lebensraum theory and nowadays with the presence of the German capital in the region. This concept was completed with the Russian (and later Soviet) claims on this region, which were asserted as part of the Yalta system, and remained a question of debate until the end of the bipolar system. Until 1918 Central Europe was a region of empires, while at the end of the First World War, instead of a potential unification, an entirely fragmented structure appeared on the ruins of the collapsed monarchies. This concept is associated with T.G. Masaryk and focuses on the presence of various smaller or bigger independent states. ${ }^{18}$

16 N. Berend, P. Urbańczyk, P. Wiszewski, Central Europe... Here the distinction can be understood as a historical line from the oldest to the youngest. Old Europe is the heritage of Charles the Great's empire, while younger, or third Europe is the result of its ambigous result of the East-West Schism.

17 P. Kaczmarczyk, M. Okólski, International Migration in Central and Eastern Europe - Current and Future Trends, United Nations (UN/POP/PD/2005/12), New York 2005, p. 6.

18 This book was published in various languages and was serving as a background study for the delegates of the Peace Conference. He compared the German efforts and the strategy of the Allies before and during the war. He argued that the German efforts are anti-democratic, aristocratic and anti-national, while the Allies represent the democratic values and their programme is based upon the recognition of the claims of all nations. According to Masaryk Austro-Hungary was the vanguard of Pangermanism in the Balkans and played a role as the future colony of Germany in the Pangerman scheme and a bridge to Asia. He lso saw the Habsburg Empire as Germany's key to Turkey and through Turkey to Asia and Africa. He also recalled the attention of the Allies to keep their eyes on the Central European region as in Pangermanism he saw the threat against Russia and the Slavic nations (Kovtun, 1990). 
After the collapse of the Berlin Wall and the end of the Cold War the symbolic geography of Europe became the topic of international debate. The geopolitical reality of the Iron Curtain served as a cleavage within the continent ${ }^{19}$ representing an ideological, political and civilisation gap dividing two rival monolithic blocs. The most spectacular reshaping was recognisable between Atlantic Europe (the so-called West) and the disintegrating Soviet Union. Germany's position was special, as instead of remaining part of the so-called Mitteleuropa, belonging neither to the West nor to the East, the Western zone became an integral part of the West while the Soviet-occupied zone was integrated into the Eastern bloc. The remaining Central European countries, with Austria as an exception, became part of the Soviet sphere of interest. This division appeared in the mental map of the local population as a continuation of the historical view. Based on this perception, everything that comes from the West was considered superior, and reflecting the mental map of the 18 th century whereby the contradistinction between barbarism and civilisation can be depicted as the choice between East and West.

\section{CENTRAL EUROPE VERSUS MITTELEUROPA}

The name "Central Europe" must be distinguished from the German name, "Mitteleuropa", because while the first name rather reflects a geographical, or cultural, historical entity, the latter one expresses the importance of the region in the eyes of the German plans for the region. However, the mapping of Central Europe may be a debatable issue even for scientists, artists and politicians living in this territory. Ignác Romsics identifies the Habsburg Monarchy as Central Europe, accepting the fact that it is a constantly moving region, never immutable. ${ }^{20}$ Hanák shared this idea emphasizing the constant chageability of this region based on the historical events. Central Europe may variously include or exclude the Czech territory, Austria, and Germany; it may incorporate the Carpathian Mountains and be a bridge to the Balkans; it may be identified as the sign of German imperialism. One can speak of the resurrection of Central Europe and be called an absurd appearance of the German imperialism." ${ }^{21}$

The idea of Middle Europe was strongly connected with post-Napoleonic French initiatives to assist in the creation of a narrow belt between imperial Russia and the unifying German state with the participation of the Habsburg Monarchy called Mitterleuropa from the beginning of the twentieth century. It concentrated among others the French efforts to gain control over this region referring the "Eastern Question", the declining Habsburg Monarchy and the more and more determining national question. Metternich was the first politician who used the word Mitteleuropa for the first

19 A. Sorin, “A románok 1995-ben: szimbolikus földrajz és társadalmi identitás”, Magyar Kisebbség, no. 4 (1996).

20 I. Romsics, “Közép- és/vagy Kelet-Európa - egy definiciós vita és ami mögötte van”, Korunk História, no. 7 (2016), at <http://epa.oszk.hu/00400/00458/00549/pdf/EPA00458_korunk_2016_ 07_074-089.pdf>, 22 September 2018.

21 P. Hanák, “Közép-Európa keresi önmagát”, LIGET Mühely, 2018. 
time. This construct emphasized the role of the Habsburg Empire and described Central Europe as a geographical rather than political unity. The concept of so-called Mitteleuropa became widespread in the first years of the First World War when Friedrich Naumann composed his vision and the German role in this construct. The concept of German-led Mitteleuropa was popular as long as the Axis powers were in the winning position. Their defeat and the breakup of the Habsburg Monarchy into successor nation states redefined it.

The German imperialism created for itself a different model and Friedrich Naumann was the expert of this idea. German Mitteleuropa and the East-Central Europe could be identified with the imperial claims of Germany emphasizing the importance of Germans in that region. After the collapse of the Habsburg Monarchy these German claims obviously had to weaken and the structure of the new independent small states got a new name, Zwischeneuropa. ${ }^{22}$ This concept was the extension of Haushofer's theory regarding Mitteleuropa. He identified this region, the chain of the states of the Little Entente, as the buffer zone created by France, emphasizing the French claims towards control over this region. His theory was followed by Viktor Bauer's concept in 1936. In his work, Zentraleneuropa he focused on the natural borders of this region taking the geomorphological, geographical, historical and botanical elements into consideration. In Bauer's vision the Central European region borders on Danzig, Trieste, Valona, Constantinople, Odessa and Königsberg. The Hungarian views, however, emphasized more the federalist approach with the exclusion of the Germans and neglecting the German efforts. Both Jászi and József Csetényi focused on the Danube basin as the core around which the reorganisation of the fragmented Central Europe could proceed. Whioe Jászi, already as an émigré, expressed the necessity for peaceful federative cooperation of the new small successor states, Csetényi himself underlined the importance of revisionism as a natural and necessary consequence of the decision that disintegrated the Habsburg Monarchy. ${ }^{23}$ The territorial frames were frequently changing in the past centuries. The German territorial expansion, the „Drang nach Osten” became the main organising force and the first sign of German imperialism. ${ }^{24}$ The presence of the Germans was a general phenomenon in this region and the monarchies of the region tried to find the adequate answer to this challenge.

22 P. Miletics, V. Pál, “A közép-európai...”, p. 223.

23 Azt a Magyarországot akarják megcsinálni, mely nem eszköze más hatalomnak, amely a maga életét éli, a maga életcéljait tűzi ki, amelyre szüksége van a világnak is a Dunavölgye újjárendezésénél és amelybe bekapcsolódhatnak Erdély, Horvátország, a Felvidék életcéljai, sőt be kell kapcsolódniuk, mert életcéljaik gyökérzete közös. (We want to recreate such Hungary that is not any more a toy of any great power, that can declare about its aims by itself, the Hungarian state that has a great importance in the reorganisation of the Danube valley, the concept which is acclaimed by the world and to which the aims of Transylvania, Croatia and Upper Hungary (the territory of Slovakia) can be also included, first of all because their aims are similar. 


\section{UNCERTAIN BORDERS}

While relating the problems of borders to the identification of Europe it is obvious that 'Europe' can be identified as a concept as well as a continent, and the borders of both oscillate wildly. ${ }^{25}$ According to this interpretation, in the Middle Ages, Europe became virtually synonymous with Christendom. A relatively recent and generally unaccepted theory sees Europe spanning half the globe, from Iceland to the Bering Strait, nearly touching Alaska. In the past centuries, the unity was internationalized and less formalized/theorized. Religious ambitions or cultural projects united the Europeans, because Europe was rather a spiritual ideation. ${ }^{26}$ As Maci emphasizes, during the Cold War, however, the opposite tendency triumphed more often: all of the Soviet Union, including Vilnius, Riga and other cities that today lie within the European Union, were excluded from Europe entirely. At times even the Soviet satellite states in the Warsaw Pact were left out, as well, so much had "Europe" come to be synonymous with "the West" and its associated political values. The internal cleavages or borders of Europe were a forgotten issue at the time of the Cold War. The Central and Eastern European region was treated as a homogenous entity matching Russia's so-called zone of influence. As perceived by the West, Europe ended at the Iron Curtain and everything located beyond it was part of the group of satellite states within the Soviet Union's sphere of interest.

The phenomenon of borders got its importance with the birth of nation states in the $19^{\text {th }}$ century and retained it through several decades. After the First World War, with the collapse and the disappearance of the great empires in Central and Eastern Europe, state borders strengthened their separatory role. While mutable borders are a sign of life, closed borders signify ethnic or political division and often literally cause death. Even in peace borders have often been perceived as dead zones, peripheral regions separated from the national "core", from its wealth, power, and independence. ${ }^{27}$ When the wall, border, or boundary is closed or remote, these zones usually function as conquered, relatively empty second-class areas. ${ }^{28}$

Establishing borders was always a great challenge in the Central and Eastern European region. Given that for many decades three great powers divided the territory between their zones of influence, it is rather difficult to speak of a common decision based on the interest of the local people. Historical and national claims expressed recalling

25 F. Jacobs, Where Is Europe, at <https://opinionator.blogs.nytimes.com/2012/01/09/where-is-europe/>, 22 September 2018.

26 D. Maci, "East European Identity versus West European Identity", Annales Philosophici, no. 3 (2011), pp. 30-36.

27 M. Silberman, K.E. Till, J. Ward, Walls, Borders, Boundaries, Spatial and Cultural Practices in Europe, New York-Oxford 2012, pp. XV-XVI.

28 The Polish Central Industrial Region is a typical example of this issue. In the inter-war period, a Central Industrial Region was established in the central area of Poland. As a consequence of the territorial changes based on the agreement in Potsdam in 1945 the Polish borders generally shifted westward and the Central Industrial Region found itself in the Eastern borderland of Poland. 
even violent events that usually ended with the brutal intervention of the ruling power warning the insurgents, not to oppose the imperial interest by causing instability. As Bialasiewicz's classification describes decisions about borders made for various reasons. Borders can be created from above, by the state, which naturally does not necessarily reflect the interest of the local population. Borders can be drawn from outside, too. Usually that happens in the aftermath of a war and in the majority of such cases, it is usually only the winners who have the chance to express their will. It may be observed in a few instances that such decisions seemed to serve only as temporary solutions and in many cases, they triggered further conflicts and lack of cooperation among the offended partners. ${ }^{29}$ Borders can also be established from inside as a consequence of claims to nationhood, although that is a rather risky solution from the ruling partner. Giving autonomy or even supporting the attempts at independence can have dual consequences. Through the reconciling of the insurgent nations and political actors can increase the internal stability of the state and can serve as an example for the rest of the other nations in their fights for autonomy. In Central and Eastern Europe, ethnic and political borders have rarely coincided in the past two centuries and instead of homogeneous structures, multi-ethnic states were dominant.

Distinction and the construction of identity conveys the differentiation between $m e$ or $u$ and the other. The individual, connected to certain norms and values, is located "here", whereas the other is accross the borderline, in the next village, in another region, in another country, or indeed, in Central Europe or in Eastern Europe, in the European Union, in Russia. Each scale requires an adequate geopolitical imaginery.

Borders play what one might refer to as a socio-spatial role for the individual living in its vicinity, since for them it is part of daily spatial practice, whereas for someone else, living far from it, the border is more of a social construct of statehood. The visibility of historical borders sometimes reflects the electoral maps and demonstrates how historical territorial limits of a state become visible regardless of the fundamental escalating processes that have occurred in these states during the last 150 years. ${ }^{30}$

The improvement of national identity in the age of modernization took place parallel with the development of regional identity. The $19^{\text {th }}$ century was the age of birth of nation states however regarding the position of the nations in Central and Eastern Europe the monarchies and empires under dynastic order were much more widespread. That determined the fate of the nations living under foreign supremacy, but at a certain point, it also helped them to strengthen the attempts to achieve autonomy or later, independence.

29 When we look at the inter-war history of Poland, the conflict between Poland and Lithuania is a very good example of the lack of cooperation. The lack of cooperation was a weak point in the relation of Hungary and the successor states of the dissolutig Austro-Hungarian Monarchy. The consequences of the Trianon treaty and the loss of the majority of Hungary' territory after 1920, also determined the frames of the Hungarian government's foreign policy. Everything was subordinated to the idea of territorial revision and that was the reason for the mutual suspicion between Hungary and the neighboring successor states.

30 S. von Löwis, "Phantom Borders in the Political Geography of East Central Europe: An Introduction", Erdkunde, vol. 69, no. 2 (2015), pp. 99-105. 
Central Europe is usually defined as a zone, or a cleavage between East and the West. As Denni remarks in her paper on the phantom borders and the bordering of Europe, the Central European region can be characterised as a conflict zone, on the one hand, but she also remarks that the history of the region is characterized by two tendencies, namely the idea of unity, which implies striving for a homogeneous region, and resistance to these efforts and the struggle for the autonomy of the people living in Central Europe. ${ }^{31}$ The location of Central Europe in terms of the all defined divide between West and East, one that moreover tended to shift during the course of history, was by no means fully clear and has been, indeed, the subject of several debates.

The Hungarian historian, Jenő Szücs emphasizes its in-between position, which provides it with an opportunity to adopt Western values and retain Eastern traditions at the same time. One can doubt if this position is treated as an advantage or as a position that hampers the orientation towards the West. Hanák on the other hand, explains the division as a consequence of belated embourgeoisement. ${ }^{32}$ He points out that this missing social class was replaced by the nobility and instead of the French traditions imbued with the principles of the Enlightenment, the romantic German visions became widely accepted. Based on this perception, as Hanák remarks, from this quite archaic idealistic perception a relatively direct path led to social Darwinism and later on, to racism. It is still questionable what territorial scope is understood by Central Europe from the Hungarian point of view, as for many historians only the Habsburg Empire served as a reference point in their disputes.

This Central European region thus served as a melting pot of several ethnic groups and religions, which lived in peaceful conditions despite the fact that the region was attacked from time to time from different directions. The $19^{\text {th }}$ century, however, brought an end to the peaceful coexistence of different groups as nationalistic ambitions determined the future of the local population. The late $19^{\text {th }}$ century was influenced by the linguistic nationalism that became widespread in the three historical states: in the Polish, the Czech and the Hungarian community. They were in discrepant positions, without independence and incorporated to different empires. Each of them was quite ambitious in referring to the glorious historical past that was in contradiction with the unstable present and the restoration of their former territories by developing into monolingual communities. By this these nations professed the primacy of linguistic issues, which would finally lead to the national awakening of those nations whose statehood had not been recognized previously. ${ }^{33}$ The First World War made this situation even more complicated as in these confusing times different nations raised their demands to a new level, i.e. that of an independent nation state. The reign of linguistic nationalism finally led to the plasticity of borders in the Central European region. In Western and Northern European cases, the historical status quo helped to maintain the

\footnotetext{
31 K. Denni, “Central Europe as a Transition Zone...”, p. 64.

32 P. Hanák, "Közép-Európa keresi...”.

33 I. Bibó, "A kelet-európai kisállamok nyomorúsága”, in I. Bibó, Válogatott tanulmányok, I. 1935-1944, Budapest 1986, pp. 185-265.
} 
importance of nation building as the old borders in Central Europe either became lost (in the Balkan) or weakened and led to desperate disputes about the new borders. The final decisions were eventually imposed violently by the great powers, but until that happened there was a lot of suffering everywhere. Speaking about another critical zone Appelbaum remarks that national demands could develop into armed conflicts quite easily. During the five years of Russian and Polish War at least 11 different armies were fighting for the future Ukraine ${ }^{34}$ and the last battle in 1920 caused the death of more than 20,000 cavalrymen. The new borders disappointed both the winners and the losers and hampered the cooperation among the new states in the decades to come. As Churchill remarked, "when the war of giants is over the wars of pygmies will begin." ${ }^{35}$

Borders are good examples of otherness that was constructed by separate trajectories and incompatible developments. ${ }^{36}$ Borders formulated the mental maps of Central Europe as they acted as the borders of the Empire of Charlemagne, which separated Christian Europe from the Slavs in the East, and then the borders drawn by the Reformation and Counter-Reformation of the sixteenth century. Moreover, the borders between the Latin West and Orthodox East, or between Christendom and Islam have to be considered. The old borders influenced the social, cultural, and political life of the peoples living between them and were a marker of difference. The impact of these invisible borders can be seen even nowadays, and provides arguments for excluding from Central Europe those who are considered as Others, such as the Balkan peoples. ${ }^{37}$ Denni's argumentation corresponds with Sorin's remarks regarding the problem of the mental map of Europe. Sorin argues that even for the generations after 1945 the mental map of Europe still perpetuates the stereotypes about the more developed and the more backward parts of Europe. Since the age of Enlightenment there was a general perception that development would obviously come from the West, but until the Great Discoveries and the first roots of Capitalism, the South represented civilisation (see ancient Greece and Roman Empire) while the North was identified with barbarism. From the 18th century onwords the symbolic division between North and South was replaced and the boundary between barbarism and civilisation could be drawn along the East-West axis. The Ottoman invasion and the occupation of the Kingdom of Bohemia and the end of sovereignty for both Poland and Hungary also deepened the East-West division.

34 A. Appelbaum, Kelet és Nyugat között - Európa határvidékén, Budapest 2016, pp. 16-17.

35 This sentence has a feeling that Churchill was speaking from the perspective of a representative of a great power but this unstable region has repeatedly caused and still can cause conflicts and international political crises. At <http://www.quoteauthors.com/winston-churchill-quotes/>, 22 September 2018.

36 It is very popular to deal with the division of Europe. The core and periphery theory by Wallerstein is based on the same ideology that was also described by the Hungarian historian Jenő Szücs in his work: Vázlat Európa három történeti régiójáról in the early 1980s. J. Szűcs, "Vázlat Európa három történeti régiójáról”, Történelmi Szemle, no. 3 (1981), pp. 313-359. The importance of this essay - apart from the intention to provide a synthetic comparison of the different regions of Europe - was its delicate timing. The essay was published in the early 1980 s and claimed that there was no homogeneous Eastern Europe.

37 K. Denni “Central Europe as a Transition Zone...”, p. 62. 


\section{CENTRAL EUROPE - AN EXPERIMENT}

Central Europe can also be explained as an experimental region characterized by an ambiguous approach towards modernity. One of the most visible differences between the Eastern and the Western European approach can be observed in relation to social integration. Hanak calls it the position of a ferry, adopting the idea from the famous Hungarian poet and representative of Hungarian political journalism, Endre Ady. Returning back from Paris and strongly influenced by Western political ideology, Ady compared Hungary to a ferry drifting between two banks of a river unable to stop. Ady did not survive the years after the First World War that led to the territorial changes and the dissolution of the Habsburg Monarchy, with Hungary losing approximately two-thirds of its original territory and the majority of its nationalities. The comparison of Hungary to a ferry between the East and the West, however, is very accurate in the context of the Hungarian political culture. ${ }^{38}$ It might refer to instability towards modernism, one that can develop into a general social crisis in Central Europe.

As an uncertain entity, Central Europe has received a variety descriptions. One of the bizarre names was "invisible snail shell." ${ }^{39}$ With this remark Szilágyi-Gál emphasizes the experience that despite European integration and the opening of the borders, which resulted in the free flow of peopleand information, the old experiences and views are still visible,in particular in terms of cultural and existential challenges, especially the financial gap between East and West. There are other perceptions that focus on the question of Central Europe as a sign of revolt against the decision of great powers, the revolt against the Yalta system. However, at the same time this revolt focuses on the relation with the West and the special ties with history. ${ }^{40}$ The relation to Central Europe can be different from the point of view of the investigators. Losoncz Alpár recalls the Serbian standpoint that was rather controversial when it comes to the division of Europe and the territory of Yugoslavia. From the Serbian point of view Central Europe was identified with regional imperialism personified by Croatia and Slovenia. ${ }^{41}$ Apart from these two regions in Yugoslavia, the Voivodina region was also a weak point of in Yugoslavian cohesion. The Serbian idea of Central Europe was usually associated with a debate on inclusion and exclusion; it was also pervaded with the idea of

38 "Kompország, Kompország, Kompország: legképességesebb álmaiban is csak mászkált két part között: Kelettől Nyugatig, de szívesebben vissza." (Ady) The metaphor of a "ferry country" (found in the first part of 'Ismeretlen Korvin-kódex margójára') not only presents a choice between the 'barbarian' East and the 'civilized' West, Asia or Europe, it is also a rewriting of the East/West opposition (a central topic of the area's intellectual history) and the Hungarian national character from a more provocative and tragic standpoint. At <http://hungarologia.net/wp-content/uploads/Teslar-Akos-rezumehu.pdf>, 22 September 2018.

39 M. Szilágyi-Gál, "A fal közöttünk", in Közép Európa, felejtsük el?, at <http://ketezer.hu/2015/02/ kozep-europa-felejtsuk-el-3/>, 22 September 2018.

40 S. Horváth, Kell nekünk Közép-Európa (is), in Közép-Európa - felejtsük el?, at <http://ketezer. hu/2015/02/kozep-europa-felejtsuk-el-3/>, 22 September 2018.

41 A. Losoncz, "Velük elkezdődhetne", in Közép-Európa - felejtsük el?, at <http://ketezer.hu/2015/02/ kozep-europa-felejtsuk-el-5/>, 22 September 2018. 
superiority in civilisation and of the attempts at internal colonialization. That process was in accordance with the idea that "Balkan" equalled "backward". As "Balkan" meant something underdeveloped, of second-class quality, nobody wanted to belong to the Balkans. Eastern Europe was also such a phrase that it was better to avoid using. The definition of Central Europe was also uncertain. It was more or less accepted that just like the name Balkans the phrase Eastern Europe, as the Central and Eastern European region was identified, also had some kind of negative connotation. That corresponds with the argumentation by Romsics, who quotes the recent Hungarian ambassador in Berlin, Döme Sztójay the Hungarian prime minister in 1944. In a meeting with German partners he exclaimed arguing that identifying Hungary with the Balkans could be defined as a hurt to Hungary. ${ }^{42}$ Maybe that was the reason why the US administration demanded in the 1990s that those states that were already in negotiation of the Euro-Atlantic integration should be referred to as Central Europe in order not to hurt them by declaring them part of Eastern Europe.

Hanak also emphasized the common cultural values such as the appearance of different styles in architecture and in the arts. Although the renaissance and the principles of humanism appeared in several parts of the region they were present only sporadically. The Reformation and the Counter-Reformation also influenced the mentality of the local population; however, both had to struggle with the adversities brought about by the presence of the Ottoman Empire. As Hanak remarks, the flourishing Counter-Reformation served as a natural obstacle to the ideology of Enlightenment and the development of the natural sciences, not to mention the first signs of capitalism. $\mathrm{He}$ found the Baroque style as an organising force and a connecting element that was present in music, opera, ballet, palaces and the comprehensive modern urban landscape from Munich to Salzburg, from Prague to the smallest Hungarian villages. This Central European universalism got the first push in the early 19th century with the influence of nationalism. The Habsburg Monarchy could be defined as an outstanding example of multiculturalism, and religious and linguistic heterogeneity with the German language as the main element of cohesion and the influence of the Jewish population as one of the most "cosmopolitan" groups. A similar standpoint is represented by Czeslaw Milosz. "For the Lithuanian-born Pole Central Europe encompassed a whole swathe of territory that ran from „Baroque Vilnius” in the north to "medieval Renaissance Dubrovnik" in the south, encompassing pretty much everything that lay to the east of Germans but was predominantly Catholic and Jewish in heritage." ${ }^{33}$

This multiculturalism, multiethnicity was interrupted by the decisions of the new territorial structure of the region. Paradoxically, despite the almost one hundred years that have passed since the collapse of the great empires and the birth of the successor states,

42 Ne beszéljenek Magyarországról mindig úgy, mintha az a délkelet-európai térséghez vagy Délkelet-Európához tartozna. Magyarország nem számítja magát a Balkán-népekhez, és sértésnek érzi, hogy mindig egy kalap alá számítják. (Don't speak about Hungary as being part of the Southeastern region, or Southeastern Europe. Hungary does not treat itself as part of the Balkan region and takes it as hurt being evaluated equal with them.) In I. Romsics, "Közép- és/vagy Kelet-Európa...”.

43 At <https://www.eurozine.com/growing-up-in-kunderas-central-europe/>, 22 September 2018. 
these signs of multicultural structure and heterogeneity are still visible in particular at the two parts of state borders, in particularly if these borders divided previous coexistences. The most spectacular elements of this heritage can be observed through loanwords and family names that indicate a long lasting community with its roots deep in the past.

The multi-ethnic mixture can be also recognised in the variability of religions. It is also a characteristic element of the Central European history that due to its multi-ethnic and multilingual structure, ethnic conflicts usually developed into language conflicts and the imperial aspirations became visible through language conflicts. Language preference is a delicate issue in particular in the Central and Eastern European region. Language is suitable to provoke and to remind a certain way of colonisation and to demonstrate the supremacy or the subordinated position. ${ }^{44}$ Those who were capable of using their language, remained conquerors while those whose languages came to be supressed themselves felt as a colonised population.

As Breully remarks ${ }^{45}$ the nation must be as independent as possible, which usually requires at least the attainment of political sovereignty. Following this argumentation Von Lowe goes further, stating that "although not all aspects of regional identity are necessarily political, but first of all social and cultural, most layers of dimensions of regional identity or belonging can eventually been politicised - such as, for instance, language or religion - and can be used for political concerns.... spatially mediated identity even on local level might then be the result of geopolitical conceptions of space through media or school textbooks." ${ }^{46}$ According to Bibó's opinion the roots of nation states go back much earlier than the beginnings of modern states. One of their features is the use of language or at least a group's own dialect. Monolingualism, as Bibó remarks, was a natural consequence of political, cultural or religious hegemony of the predominance of stronger monarchies. Obviously, several European language borders preserve the memory of the earlier political borders. ${ }^{47}$ The Habsburg Monarchy that was established and strengthened after the Ottoman occupation and at the axis of the German-Roman Empire was far from being a construct created around the Danube. It was part of the Holy Roman Empire until 1804 with disintegrated provinces from the Northern Italian region to the Bohemian lands and, as Bibó remarks, from the outer perspective the incorporated Hungarian Kingdom was seen as a military base in the East serving the German interest. As a consequence of the War of Austrian Succession in the mid-18th century and the incorporation of a greater chunk of the partitioned Polish Kingdom made the Habsburg Empire more fragmented. The Polish question, as Bibó remarks, was far more than the plans as to how to erase Poland from the map of Europe, but rather the realization of the Prussian plans for unification of the East Prussian lands with the West Prussian lands that had been divided after the triumph of the Polish Kingdom over the Prussian

44 M. Csaky, Elfelejtsük-e?, at <http://ketezer.hu/2015/05/kozep-europa-felejtsuk-el-4//>, 22 September 2018.

J. Breully, Nationalism and the State, Chicago 1985, p. 3.

46 S. von Löwis, "Phantom Borders...".

47 I. Bibó, “Az europai egyensúlyról es a békéről”, in I. Bibó, Válogatott tanulmányok..., pp. 318-319. 
Crusaders. Russia, on the other hand, wanted to get back those Lithuanian lands that had been the parts of the Russian Empire before the Tatar invasion.

The $19^{\text {th }}$ century and the idea of nation states determined and predetermined the ethnic conflicts in the future. It was the general aim of the nationalist parties and intellectuals to accept the "one culture - one nation - one state" theory, which was later modified in practice with the reconstruction of the new borders and nation states of Central Europe after the First World War. As Feischmidt remarks, there are various possibilities as to how to implement this theory in practice there are various possibilities: to change the people by forcing them to accept new values and new culture as they are capable to do it; to kill those people who are against the unity of the homogeneous socio-political community; or to resettle the dissident population to other regions; and finally, to change the political borders so that they fit better the cultural borders of the given groups of people. ${ }^{48}$ These arguments are opposite to what Hanák emphasized in his work focusing on the common values of the nations of Central Europe. He, however, mentions two elements of this phenomenon; one of them was the role of the travelling players, musicians and painters, while the other influential group was the Jewish population that was rather mobile in contrast with the rural population before the capitalist era. While, on the one hand, cultural and territorial self-awareness becomes the ruling ideology, at the royal court newer and newer plans put more emphasis on the pluralist character of the region. ${ }^{49}$

The year of 1849 became a turning point in the history of the Central European nations. The Austrian Gesamtstaat constitution was accepted as a symbol of the absolutist-pluralist concept of bureaucratic centralization, while, on the other hand, both in Prague and Pest-Buda new concepts of constitutions were discussed. After the failure of the People's Spring, in the groups of disenfranchised and stateless immigrants a new idealistic utopia of the Danube confederation was being devised alongside the idea of federalist transformation of Central Europe initiated by Adam Czartoryski in exile. ${ }^{50}$

As Hanák remarks, the Habsburg Monarchy itself was a total contradiction of values. There existed, on the one hand, an old-fashioned bureaucratic, centralized governance and on the other, a rather liberal economic policy and freedom of the flow of ideas, people and goods, together with an equally idealistic common currency, lack of censorship and a natural multilingual atmosphere among the urban population. Bibó also emphasizes several contradictions in the process of modernization. In his essay, The Deformation of Political Culture in Central and Eastern Europe he remarks that "as a result, the ending of the social role of a unified European aristocracy elicited a much greater shock in Central and Eastern Europe that in the West, where

48 M. Feischmidt, “A magyar nacionalizmus autenticitás-diskurzusainak szimbolikus térfoglalása Erdélyben”, in Erdély (de)-konstrukciók, Néprajzi Múzeum - PTE Kommunikáció és Médiatudományi Tanszék, Budapest-Pécs, 2005 pp. 7-35.

49 P. Hanák, "Közép-Európa keresi...”.

50 B. Trencsényi Balázs et al., A History of Modern Political Thought in East Central Europe, vol. 1: Negotiating Modernity in the ,Long Nineteenth Century', Oxford 2016. 
a developed social structure no longer or less typically based on birth privileges was by that time ready to take over the aristocracy's role.... All the threads point towards some kind of political hysteria, and in dismissing political hysterics the first task is to disclose the historical shocks disturbing the development and balance of these countries. We should be suspicious of two things: the premature, explosion-like character of their democracy and the resulting difficulties in the formation of the national frameworks." 51 As he further remarks "the ultimate tipping of the inner political balance was, however, due to the painful and difficult process of nation formation." He added further that "the nations living here lacked what the Western European nations possessed in a self-evident and tangible way, both in reality and in the communal consciousness: the actual existence of their own state and national framework, a capital, the harmonious functioning of politics and economy, a unified social elite, etc." The lack of democratic values and the uncertainty of their material status also led to the instability of political culture and the controversial approach towards democracy. As Bibó underlines, the approach to democracy was also a weak point in this region. Democracy was a gift that probably spread too early as the social transformation was still in a more backward, unstable position. Adapting democratic values was not the result of internal social development and as it was recognisable in various parts of Central Europe, nationalism won over democracy. Bibo linked together the acceptance of democratic values and the fear of uncertainty. The lack of stability, the reality of the limits of a group's own nationality, the missing state, the capital city, well-functioning economic and social communities, a steady elite - all these factors contributed to the development of the Western countries. The new successor states assisted in destroying Central Europe by the dissolution of the Habsburg Monarchy in 1918, which according to Hanák, was still by far the most stable construct in the region. In 1918 all dynastic entities collapsed in Central Europe and the partition of the Habsburg Monarchy was the most convenient scenario. The idea of emphasizing language borders and the possibility of self-determination was an adequate solution. The catastrophe and the roots of further conflicts, as Bibó remarks, result from inadequate implementation of the political programme of the Hungarian government by refusing ethnic unifications and neglecting historical claims to the territories offered. On the other hand, geographical, economic, strategic and infrastructural claims were taken into account, which sometimes invalidated the natural claims of the local population; the newly created borders sometimes managed to spark off further debates, in particular on whether a given ethnic group had been cut off from their historical hinterland by receiving the part of such a state or community with which they had no or limited connection in the historical past or no cultural ties. These debates sometimes are influenced by fear and uncertainty of their citizens, and on a number of occasions statistical data on ethnic composition served as a reference point in order to strengthen their claims. ${ }^{52}$

$51 \quad$ I. Bibó, op. cit. p. 331.

52 The entire Hungarian foreign policy was determined by irredentism. The German assistance in territorial claims was a good excuse of the support of the Nazi Germany. Within the territorial extension 


\section{THE REBIRTH OF THE CENTRAL EUROPEAN CONCEPT}

The Central European vision remained an idea after 1945. It was in the undead situaton until the 1980s. A new wave of debate was initiated essentially by two texts: Milan Kundera’s "The tragedy of Central Europe" from 1983 and Konrád György's "The Dream of Central Europe", published in $1984 . .^{53}$ There existed, however, a third one. Jenő Szücs, a Hungarian historian, breaking with the previous, rather Soviet-friendly, or Marxist ideology-friendly Hungarian standpoint, introduced a tripartite concept with Central Europe as a hybrid region. ${ }^{54}$ Analysing Central Europe as a separate entity he questioned the legacy of the bipolar division of Europe. ${ }^{55}$ Szücs's theory has never had such great influence in the Western world as Konrád's or Kundera's works, maybe because they both were published abroad, while Szücs was working at the Institute of History of the Hungarian Academy of Sciences in Budapest, partly in a rather isolated position, and his essay was published in Hungarian, which only added to this isolation. However, his essay provoked a general debate in Hungary already in the 1980s. What Konrád emphasized in his later works on Central Europe was that "the way from West to East leads via Central Europe." Kundera, on the other hand, believed in the early 1980s - following the disappointment with the Czech dissidents around Vaclav Havel and the Charter 77 movement - that the only hope for changing the political situation of Czechoslovakia depended on integrating the drama of his country, as well as those of its neighbours, into a broader, European context. ${ }^{56}$ As Kaczorowski remarks, Kundera managed to ensure at the same time several independent Central European circles, both in exile and in their home country. The years between 1984 and 1989 were the most flourishing period of thinking on Central Europe as both Hungarian, Polish and Czechoslovakian authors, on the one hand, and Western authors, on the other, read each other's works and got new impulse for the debate. Apart from Konrád and Kundera, Michnik and Milosz also aroused general interest among the Western intellectuals by giving them reference points to help them understand the world behind the Iron Curtain. The reasons and the influence of these debates led to various consequences. Central Europe as a phenomenon also functioned as a tool for

with the German and Italian diplomacy in the late 1930s early 1940s Hungary managed to get back the majority of those lands that were within the ethnic, language borders however at the end of the Second World War there was no supporter of the Hungarian claims.

53 The original version was read by Konrád as his acceptance speech after receiving the Herder prize at the ceremony in the Schwarzenberg Palace in Vienna in 1984.

54 I. Romsics, "Közép- és/vagy Kelet-Európa...”.

55 In the 1960s and 1970s Halecki's division of Europe, which he worked out in exile, was accepted with considerable controversy among Hungarian historians. Speaking or writing about a tripartite division with a separate Central European region that was distinct from the Soviet Union was concomitant with the denial of a homogeneous Socialist bloc. His acceptance of this structure was ambigeous even for the US audience. In Hungary it was considered to be harmful influence of a Western emigrant (and definitely a suspicious, or at least subversive, view).

56 A. Kaczorowski, Aleksander, Farewell to Central Europe, at <https://www.aspenreview.com/article/2017/farewell-to-central-europe/>, 22 September 2018. 
the opposition groups of the socialist bloc states to separate themselves from the values of the Soviet Union by demonstrating their otherness and acceptance of the Western principles, as it was recognisable in the early 1990s. These states were ready on the way towards establishing their regional cooperation models such as the Visegrad group or the Central European Initiative (previously Pentagonale and with the inclusion of Poland in 1991, the Hexagonale), pointing to the fact that from the late 1980s early 1990s Central Europe was also understood as a geopolitical concept determined to cooperate with the neighbouring countries which lay in a political and economic vacuum, already outside the Soviet bloc and but at the same time not yet quite part of the European Community. This unrepeatable moment was a challenge for the countries of the region. They had to make a great effort to abandon the deeply rooted norms and habits and focus on peaceful and effective cooperation. Apart from the optimistic views about the cohesion among the Central European states, Csaky also warns that this contribution could stagnate at a certain point. The Visegrad Group may have been a good idea for Central Europe, but as he remarks, it is a challenging issue how to find common interests between Poland, which is preparing for the position of the "regional leader", and for Hungary, which still operates in terms of the no longer existing boundaries of the Carpathian basin and is still fighting for its position on its own, and Austria, which has been transformed into a "German suburb." The position of the Central European region is rather ambiguous regarding the question of common interest. Instead of convergence towards the great Central European entity, a moderate however intensifying disintegration and uncertainty is visible. As Neumann remarks, the post-Communist countries competing with each other are moving away from the Western values they continuously refer to, on the contrary, they are somewhat demonstrating a kind of common relations with the values engaged with the South European region. Poland, as Neumann also remarks, is building a "Nordic secondary power", the "almost Austrian" Slovenia, the "best pupil" from this polychrome class, is in crisis, Hungary is fighting for its position against the West and opening its doors to the East, Germany and Austria are not really willing to cooperate with this region, and in the East, Russia is getting more and more involved with it. ${ }^{57}$

As Central Europe could be understood as a sign of self-justification of its values in the 1990 s, nowadays it can be called rather as a "lab for paradigms" where such processes took place in the past that got global importance for the present among others the treatment of differences, otherness and strangeness. ${ }^{58}$

This backwardness and the ambiguous acceptance of the initiatives coming from the West can be explained by various reasons. Kundera explains this as a consequence of the division of Europe according to the Yalta resolutions; however, as Hanák and Sik remark, ${ }^{59}$ the reason for this division must be searched a couple of decades earlier.

57 I. Neumann, at <http://ketezer.hu/2015/02/kozep-europa-felejtsuk-el-3/>, 22 September 2018.

58 M. Csaky, Elfelejtsük-e?.

59 D. Sik, A modernitás közép-európai tapasztalatáról, avagy felejtsük-e el Közép-Európát?, at <http://ketezer.hu/2015/05/kozep-europa-felejtsuk-el-4/>, 22 September 2018. 
As Ash points out, "in the first half of the twentieth century, the debate about who did or did not belong to Central Europe had real political significance. So it has today. For to be "Central European" in contemporary political usage means to be civilized, democratic, cooperative - and therefore to have a better chance of joining NATO and the EU. In fact, the argument threatens to become circular: NATO and the EU welcome "Central Europeans," so "Central Europeans" are those whom NATO and the EU welcome."

The collapse of the Berlin Wall and the end of the Cold War evoke the old discussion about the symbolic geography of the Central European region. The reality of the Iron Curtain legitimized the East-West division of Europe by introducing a political, cultural and even civilisational dividein the continent and creating two blocks; the more developed Western and the Soviet-oriented Eastern bloc. The questionable point was the location of divided Germany, which, according to the classical, historical division, for several centuries had been considered as the part of Mitteleuropa, while according to this new division under the influence of the Western powers, West Germany underwent a rapid Westernisation, while the East German state remained a stable part of the Soviet Bloc together with the remaining Central European states except Austria. ${ }^{60}$ Until the last years of Socialism, the foreign policy and the national orientation of the members of the Soviet Bloc were subordinated to the Brezhnev Doctrine. As the whole Central and Eastern European region belonged to the sphere of interest of the Soviet Union, it was hardly possible to discuss any kind of cultural, ethnic or even religious gaps. The newly defined Central Europe were discussed in the 1980s when a stronger cohesion among the oppositional groups of Polish, Czechoslovakian and Hungarian representatives began to focus on the territorial and conceptual limits of the notion. As Sorin remarks, those attempts led finally to a new wave of exclusions from the region taking shape. The result of this was the understanding of Central Europe as the heritage of post-Enlightenment Europe with Vienna as its core. This concept survived the two World Wars and the main proponent of this ideology was Kundera and his famous article, "The Tragedy of Central Europe". ${ }^{61}$ "As a result, three fundamental situations developed in Europe after the war: that of Western Europe, that of Eastern Europe, and, most complicated, that of the part of Europe situated geographically in the centre-culturally in the West and politically in the East." Kundera's standpoint got several supporters in particular from the above mentioned three Central European

60 I. Majoros, Közép- Európa nyomában... viták, vélemények a régióról, at <http://acta.bibl.u-szeged. hu/29697/1/kek_003_055-060.pdf>, 22 September 2018.

61 In fact, what does Europe mean to a Hungarian, a Czech, a Pole? For a thousand years their nations have belonged to the part of Europe rooted in Roman Christianity. They have participated in every period of its history. For them, the word „Europe” does not represent a phenomenon of geography but a spiritual notion synonymous with the word „West.” The moment Hungary is no longer European-that is, no longer Western-it is driven from its own destiny, beyond its own history: it loses the essence of its identity."Geographic Europe" (extending from the Atlantic to the Ural Mountains) was always divided into two halves which evolved separately: one tied to ancient Rome and the Catholic Church, the other anchored in Byzantium and the Orthodox Church. 
states, but it was also criticised, especially from the excluded states. ${ }^{62}$ Not only did it argue that Central Europe constituted a "kidnapped West" abducted by an alien, Byzantine-Bolshevik civilisation, but it also claimed that the rest of the continent was in too deep a state of decadence to be fully aware of what it had lost. What initially looked like a requiem, however, soon gained an altogether more optimistic sheen. ${ }^{63}$ Kundera proposes that the real tragedy of Central Europe is not solely the Soviet invasion - which for him entailed the destruction of the region's culture but rather the disappearance of culture from Western Europe. Kundera believed that Central European nations had reportedly tried to join Europe; they even managed to harbour vestiges of European culture under the oppression of Soviets while in the West, Europe changed dramatically. As she points when dissidents and émigrés entered the West, they were already disappointed the "Europe itself ... was no longer experienced as a value." ${ }^{64}$

That remark corresponds with Lengyel Lászlós opinion. Lengyel argues that this general crisis of the European values is embedded in the consequences of the two world wars. Facing the historical past immediately requires the problems of actions undertaken by the given states in the past decades or centuries to be addressed, however these actions can lead to the problem of sovereignty. The predominance of historical past, the reference points chosen in particular by the populist or nationalist politicians can even hamper the necessary cooperation. ${ }^{65}$ While Kundera believes in Central Europe, the heir to the Austro-Hungarian Empire, it is a territory of small nations tormented by a profound feeling of uncertainty over their existence; they may disappear any time just like Poland and Czechoslovakia did repeatedly, or their borders and population may change, as was the case of Hungary ${ }^{66}$ This argumentation corresponds with the phenomenon the Hungarian politicians and historians are repeatedly criticizing; the reference point for Hungarians regarding the perspectives on Central Europe in the future is still the nostalgia towards the Habsburg Monarchy and the borders of historical Hungary. The misunderstanding of the problems of the Central European region from the Western perspective can be explained because of the lack of geopolitical and historical information about this region and because of the fact that being in subordinated position, there remained limited opportunity to distinguish states being more or less adaptive towards the policy of the Soviet Union. The entire region was subjugated by Moscow and only the ability of its integration to the principles of Eastness could serve as a reference point.

62 M. Kundera, The Tragedy of Central Europe, at <http://www.kx.hu/kepek/ises/anyagok/ Kundera_tragedy_of_Central_Europe.pdf $>, 22$ September 2018.

63 J. Bousfield, at https://www.eurozine.com/growing-up-in-kunderas-central-europe/, 23 September 2018.

64 Z. Kepplová, Could the Real Tragedy of Central Europe Please, Stand up?, at <https://visegradinsight. eu/recycled-rhetoric/>, 22 September 2018.

65 L. Lengyel, Halott ország, Budapest 2016, pp. 34-38.

66 Z. Kepplová, Could the Real Tragedy... 


\section{THE LEGACY OF CENTRAL EUROPE}

"Thirty years on, most of the countries in Kundera's Central Europe have been integrated into the European Union and NATO, and the very term "Central Europe" is no longer necessary, either as an anti-Soviet rallying cry or a badge of cultural belonging. However, the cultural concerns addressed by Kundera have not necessarily gone away simply because the context has changed. Europe is still sandwiched between two superpowers with differing worldviews, and small nations can still be the bearers of important truths." ${ }^{\prime 6}$

In the 1990s two tendencies developed; the slower than expected wave of integration and the renaissance of the nation states. This latter one was common in particular in the Eastern region. As a result of transition, the post-socialist world experienced the rebirth of nation-states on the map of Europe, on the one hand, and the collapse of the Soviet Union, Czechoslovakia and Yugoslavia, on the other. The project carried out in Europe by what we call as the European Union, with its centre in Brussels. , Can it give us an identity in which we can find ourselves, an identity we can assume? ${ }^{68}$ The problems along the East-West dimension could be embraced in the discussion about EU membership, or EU scepticism. In the shadow of the referendum about Brexit, Scruton's critical argument regarding the dilemma between stronger nation states or deeper integration is still a current issue. As he says, the EU tries to demolish the territorial legal authorities such as the national faith, all the elements which are the basis of European legitimacy since the era of enlightenment. ${ }^{69}$ (Scruton, 2005)

EU membership thus can be characterized as a final proof that the transformation is over; however, it results in new problems that demand a solution. Among others the following issues can be mentioned; dangerous nationalism, xenophobia, "delocalisation", the problem of immigration and competition for cheap labour, or "social dumping." ${ }^{70}$

Analysing the perceptions of Central Europe, the region can be compared to a deity that dies and is reborn over and over again ${ }^{71}$ in the sense that at times the region is in the focus of attention of the great powers, while at others it is neglected. Looking at the position of Central Europe in the 20th century, this continuous oscillation can be traced back to the period of the First World War. During the war the region was very much an area of interest of Germany, while in the interwar period Germany became replaced by France while from the 1930s the German interest also intensified. The years between 1945 and 1947 can be characterized as an uncertain vision of great powers towards the region that was interrupted by the Soviet Union based on the decisions of the

\footnotetext{
67 At $<$ https://www.eurozine.com/growing-up-in-kunderas-central-europe/>.

68 D. Maci, "East European Identity...”.

69 R. Scruton, P. Pásztor, A nemzetek szükségességéről, Budapest 2005.

70 A. Schmidt, "The Eastern Borders of Europe - Symbolic, Historical and Cultural Aspects", in Á. Tuka (ed.), Borderless Europe. Challenges, Opportunities, Pécs 2010, pp. 39-54.

71 I. Majoros, Közép- Európa nyomában...
} 
Yalta and Potsdam conferences. Right before the transformation the French enquiry intensified beside the increasing German aspirations. The interest towards the Central European region inceases in that case if any ambitious state from the region tries to perform as an actor who pretends as a regional leader. On the other hand, if any great powers tries to rule the region it usually manages to keep them interested towards cohesion. That was visible in the functioning of the Habsburg Monarchy, in the German orientation in the interwar period, and the position of the Soviet Union after 1945. But what happens if one of the great powers loses its position? As Majoros remarks, then comes the time for nostalgia, and a discussion about the orientation, the Westernisation as it happened last time during Gorbachev's regime.

The biggest problem according to Majoros is based on the discrepancy between the expectations and the reality. He quotes György Schöpflin, a Hungarian-born English political scientist and member of the European Parliament, who stated that at the European integration in 2004 the Central European states joined an imaginary Europe and the disappointment, the negative experience, and the frustration are all based on this discrepancy.

\section{CONCLUSION}

The idea of Central Europe thus assumes some common approach to the past, common cultural values and experience that are in contradiction with the problems of its multi-ethnic structure. Although the turn of the 1980s and 1990s was filled with nostalgia reinforced by the support for the trans-Atlantic orientation and the core of the Central European region justified their Western orientation by joining the NATO and the European Union, after the first years of euphoria, more detailed, and even critical, arguments were raised in connection with the rationality of the concept of Central Europe.

„The U.S. State Department decided that Eastern Europe no longer exists. Its embassies world-wide are being instructed «that the words Eastern Europe will be banished from the lexicon» of the agency, Assistant Secretary of State Richard Holbrooke told Congress. Ha said the region will be referred to as Central Europe, as it was before 1939. Despite Europe's politically directional designations after World War II he said, «The people of the region themselves do not consider themselves Eastern Europeans»."72

Looking back over the centuries, Central and Eastern Europe has always been the playground of the great powers. , The survival of the states of this region was strongly influenced by their ability to co-operate. The euphoria of sovereignty and independence has sometimes hampered and continues to obstruct acceptance of the EU's operating institutional framework; instead of conforming, these states have shown a tendency to propose new norms that inevitably can shock the older member states and their

72 I. Romsics, “Közép- és/vagy Kelet-Európa...”. 
diplomats. ${ }^{73}$ As there was a general preconception that there existed the East, the West and a region between them that politically showed more common elements with the East but was part of the Western culture. Nowadays, after the Euro-Atlantic integration the current position of these states demonstrates just the opposite. Politically they are still the members of the European Union; however, they share much more common values with the East. Speaking about the actual problems of the East-West division nowadays the Central European issue appears to be a crucial problem in the European Union. As Pacella remarks the most questionable issues are not those of heritage and identity, but rather those of democracy. ${ }^{74}$

\section{BIBLIOGRAPHY}

\section{Literature:}

Appelbaum A., Kelet és Nyugat között - Európa határvidékén, Budapest 2016.

Ash T.G., The Puzzle of Central Europe, http://www.visegradgroup.eu/the-visegrad-book/ashtimothy-garton-the.

Berend N., Urbańczyk P., Wiszewski P., Central Europe in the High Middle Ages: Bohemia, Hungary and Poland, c. 900-c.1300, Cambridge 2013.

Bialasiewicz L., "Another Europe: Remembering Habsburg Galicia", Cultural Geographies, vol. 10, no. 1 (2003), https://doi.org/10.1191/1474474003eu258oa.

Bialasiewicz L., "Europe as/at the Border: Trieste and the Meaning of Europe", Social and Cultural Geography, vol 10, no. 3 (2009), at <https://doi.org/10.1080/14649360902756655>. Bibó I., "A kelet-európai kisállamok nyomorúsága", in I. Bibó, Válogatott tanulmányok, I. 1935-1944, Budapest 1986.

Bibó I., “Az europai egyensúlyról es a békéről”, in I. Bibó, Válogatott tanulmányok, I. 1935-1944, Budapest 1986.

Breully J., Nationalism and the State, Chicago 1985.

Csaky M., Elfelejtsük-e?, at <http://ketezer.hu/2015/05/kozep-europa-felejtsuk-el-4//>.

Denni K., "Central Europe as a Transition Zone between East and West", Traditiones, vol. 38, no. 2 (2009), https://www.doi.org/10.3986/Traditio2009380205.

európai világgazdaság eredete a XVI. században, Budapest 1983.

Feischmidt M., "A magyar nacionalizmus autenticitás-diskurzusainak szimbolikus térfoglalása Erdélyben”, in Erdély (de)-konstrukciók, Néprajzi Múzeum - PTE Kommunikáció és Médiatudományi Tanszék, Budapest-Pécs 2005.

Hanák P., “Közép-Európa keresi önmagát”, LIGET Mühely, 2018.

A. Schmidt, "Friends Forever? The Role of the Visegrad Group and European Integration", Politics in Central Europe vol. 12, no. 3 (2017), pp. 113-140.

74 This time, it is nothing to do with heritages, history and common culture. It is only about how the states of Central Europe face current problems and issues.... If, before, the cause of increasing the Europe's East-West divide was a need to achieve the Western democracy, today is the lack of democratic values who divides the West from the East. At <http://www.fomoso.org/en/opinions/commentaries/the-new-tragedy-of-central-europe/>. 
Hardi T., "Various Mental Images about the Geographical Extension of Central, Southeast and Eastern Europe”, Bulletin of Geography. Socio-economic Series, no. 31 (2016), https://www. doi.org/10.1515/bog-2016-0009.

Havel, Vaclav: "Allocution prononcée devant la Diéte et le Sénat polonais. Varsovie, le 25 janvier 1990", in L'angoisse de la Liberté, Paris, Éditions del'aube, in K. Denni, “Central Europe as a Transition Zone between East and West”, Traditiones, vol. 38, no. 2 (2009), https://www. doi.org/10.3986/Traditio2009380205.

Horváth S., Kell nekünk Közép-Európa (is), in Közép-Európa - felejtsük el?, at <http://ketezer. $\mathrm{hu} / 2015 / 02 /$ kozep-europa-felejtsuk-el-3/>.

Illés I., Közép-és Dél-Kelet-Európa az azredfordulón, Budapest 2002.

Jacobs F., Where Is Europe, at <https://opinionator.blogs.nytimes.com/2012/01/09/whereis-europe/ $>$.

Kaczmarczyk P., Okólski M., International Migration in Central and Eastern Europe - Current and Future Trends, United Nations (UN/POP/PD/2005/12), New York 2005.

Kaczorowski A., Farewell to Central Europe, at <https://www.aspenreview.com/article/2017/ farewell-to-central-europe/>.

Kepplová Z., Could the Real Tragedy of Central Europe Please, Stand up?, at <https://visegradinsight.eu/recycled-rhetoric/>.

Közép Európa. Felejtsük el?, at <http://ketezer.hu/2015/05/kozep-europa-felejtsuk-el-5/>.

Kundera M., The Tragedy of Central Europe, at <http://www.kx.hu/kepek/ises/anyagok/Kundera_tragedy_of_Central_Europe.pdf>

Lengyel L., Halott ország, Budapest 2016.

Losoncz A., "Velük elkezdődhetne", in Közép-Európa - felejtsük el?, at <http://ketezer. hu/2015/02/kozep-europa-felejtsuk-el-5/>.

Maci D., "East European Identity versus West European Identity”, Annales Philosophici, no. 3 (2011).

Majoros I., Közép- Európa nyomában... viták, vélemények a régióról, at <http://acta.bibl.u-szeged.hu/29697/1/kek_003_055-060.pdf>.

Miletics P., Pál V., “A közép-európai tér fejlődésének kérdései”, Földrajzi Értesitô, no. 2 (1998).

Okey R., "Central Europe / Eastern Europe, Behind the Definitions", Past and Present, vol. 137, no. 1 (1992), https://www.doi.org/10.1093/past/137.1.102.

Romsics I., "Közép- és/vagy Kelet-Európa - egy definiciós vita és ami mögötte van”, Korunk História, no. 7 (2016), at http://epa.oszk.hu/00400/00458/00549/pdf/EPA00458_ korunk_2016_07_074-089.pdf>.

Schmidt A., "Friends Forever? The Role of the Visegrad Group and European Integration", Politics in Central Europe vol. 12, no. 3 (2017), at <https://doi.org/10.1515/pce-2016-0019>.

Schmidt A., "The Eastern Borders of Europe - Symbolic, Historical and Cultural Aspects", in Á. Tuka (ed.), Borderless Europe. Challenges, Opportunities, Pécs 2010.

Scruton R., Pásztor P., A nemzetek szükségességéről, Budapest 2005.

Sik D., A modernitás közép-európai tapasztalatáról, avagy felejtsük-e el Közép-Európát?, at <http://ketezer.hu/2015/05/kozep-europa-felejtsuk-el-4/>.

Silberman M., Till K.E., Ward J., Walls, Borders, Boundaries, Spatial and Cultural Practices in Europe, New York-Oxford 2012. 
Sorin A., “A románok 1995-ben: szimbolikus földrajz és társadalmi identitás”, Magyar Kisebbség, no. 4 (1996).

Szilágyi-Gál M., “A fal közöttünk”, in Közép Európa, felejtsük el?, at < http://ketezer.hu/2015/02/

kozep-europa-felejtsuk-el-3/>.

Szűcs J., "Vázlat Európa három történeti régiójáról”, Történelmi Szemle, no. 3 (1981).

Trencsényi B. et al., A History of Modern Political Thought in East Central Europe, vol. 1: Negotiating Modernity in the ,Long Nineteenth Century', Oxford 2016.

von Löwis S., "Phantom Borders in the Political Geography of East Central Europe: An Introduction", Erdkunde, vol. 69, no. 2 (2015), https://www.doi.org/10.3112/erd kunde.2015.02.01.

Wallerstein I., A modern világgazdasági rendszer kialakulása. (A tökés mezögazdaság és az europai vilaggazdasag eredete a XVI. szazadban, Budapest 1983.

\section{Internet sources:}

http://hungarologia.net/wp-content/uploads/Teslar-Akos-rezume-hu.pdf

http://www.fomoso.org/en/opinions/commentaries/the-new-tragedy-of-central-europe/ http://www.fomoso.org/en/opinions/commentaries/the-new-tragedy-of-central-europe/ http://www.quoteauthors.com/winston-churchill-quotes/ https://www.eurozine.com/growing-up-in-kunderas-central-europe/ https://www.eurozine.com/growing-up-in-kunderas-central-europe/ https://www.gla.ac.uk/0t4/crcees/files/summerschool/readings/school10/reading_list/Sinnhuber.pdf

Andrea SCHMIDT, PhD - a political scientist and an Associate Professor at the University of Pecs, Hungary, Department of Political Sciences, and International Studies and former Visiting Lecturer and the Josai Institute for Central European Studies Josai International University, Tokyo, Japan, and Visiting Lecturer at Ivan Franko National University in L'viv, Ukraine. She studied at the University of Pecs, the Eötvös Lóránd University in Budapest and at the Central European University where she participated at Modern History programme focusing on Central and Eastern Europe. She also studied at the Jagiellonian University at the Faculty of History and at the Polonia Research Institute in Cracow, Poland. She specializes on International Political Economy and Comparative Political Studies of the Central and Eastern European region. She did her habilitation on International Relations focusing on Geo-economics. She is author of several articles and book chapters related to Central and Eastern European and post-Soviet region. 